\title{
Maximum Power Point Tracking Control of Photovoltaic System using Fuzzy Logic Controller based on Incremental Conductance Technique
}

\author{
K. B. Zirata \\ Department of Electrical \\ and Electronic \\ Engineering, \\ Adamawa State \\ Polytechnic Yola
}

\author{
A. S. Kadalla \\ Department of Electrical \\ and Electronic \\ Engineering, \\ Moddibo Adama \\ University of Technology \\ Yola
}

\author{
I. T. Thuku \\ Department of Electrical \\ and Electronic \\ Engineering, \\ Moddibo Adama \\ University of Technology \\ Yola
}

\author{
Angeti Jival \\ Department of Electrical \\ and Electronic \\ Engineering, \\ Moddibo Adama \\ University of Technology \\ Yola
}

\begin{abstract}
This paper focused on the design of Maximum Power Point Tracking (MPPT) for extracting maximum power from solar panel to improve the efficiency of the PV system by introducing maximum power point tracking techniques. Fuzzy Logic Control (FLC) algorithm was developed using the incremental conductance technique for MPPT. The simulated results reveal that the FLC has better performance which has suppressed the oscillation around the MPP than the Perturb and Observe $(\mathrm{P}$ and $\mathrm{O})$ controller which has much oscillation around the MPP.
\end{abstract}

\section{General Terms}

Solar energy, Concept of MPPT, fuzzy logic, system modeling

\section{Keywords}

MPPT, PV system, FLC, incond, $\mathrm{P}$ and $\mathrm{O}$

\section{INTRODUCTION}

Solar energy is reflected as the fundamental of renewable energy in modern times mainly because of the exhaustion of fossil fuels and it's ecological approachability, infinite nature, unrestricted, and unpolluted [1]. Amid numerous renewable energy resources, photovoltaic (PV) systems are gaining reputation in a wide range of uses, from small structure incorporated systems to big scale service systems.

A photovoltaic cell is a semiconductor device that converts light to electrical energy by photovoltaic effect [2]. If the energy of photon of light is larger than the band gap then electrons are discharged and the flow of electrons generates current. Cells may be assembled to form panels or modules, and panels can be assembled to form big photovoltaic arrays [3].

The key limitation to the extensive spread usage of PV system is the low efficiency of the PV module due to Variations in ambient conditions (irradiation) [4]. The current -voltage (I$\mathrm{V})$ or power-voltage $(\mathrm{P}-\mathrm{V})$ curve of a photovoltaic system describes the characteristic of the PV module for a set of temperature and irradiance. An operating point on the P-V curve matches to a typical power that is produced and delivered to the rest of the PV systems and finally the load. It is therefore clearly beneficial that a solar module operates at maximum power. Without any form of external electrical manipulations, the PV module's operating point is mostly dictated by the electrical load seen at its output. To get maximum power supplied by the PV system, it is very necessary to force the PV module to operate at the operating point conforming to the maximum power point. This is the ultimate of the P-V curve or the knee of I-V [5].

The simplest way to make the PV module to operate at maximum power point is to force the voltage of the PV module to be at the maximum power point or to control the current at the right amount as that of the maximum power point using converters.

To constantly maintain the operating of PV module at maximum power point regardless of variations in ambient conditions, there is need to track any such variations on the I$\mathrm{V}$ or P-V curve and trace the new MPP. This process is called maximum power point tracking (MPPT).

Numerous algorithms are engaged to track MPP efficiently, but prominent amongst them include the $\mathrm{P}$ and $\mathrm{O}$ technique [6], and the incremental conductance method [7]. In perturb and observe algorithm, numerous voltage perturbations are delivered to the PV module which could increase or decrease the output power. This approach, the algorithm converges towards the maximum power point. The algorithm essentially takes advantage of the point that the P-V curve has an increasing nature to the left of MPP and a decreasing nature to the right. The problem with the $\mathrm{P}$ and $\mathrm{O}$ algorithm is that, the operating point is never stable at the maximum power point. It is always hovering about in the area of the MPP. The P and O also struggle under rapidly varying radiances. This is detrimental to the rapidity of convergence which is one of the critical figures of merit in the fields of maximum power point tracking techniques. Thus, the drastic variation in weather conditions severely affects the $\mathrm{P}$ and O's effectiveness. The Incremental Conductance (IC) technique on the other hand adventures the fact that the P-V curve has a positive slope to the left of MPP, a negative slope to the right and zero slopes at the maximum power point. The IC algorithm has proven to be more effective at MPP as it does not hover in the MPP area under stable state like the $\mathrm{P}$ and $\mathrm{O}$ algorithm. The main drawback of the IC algorithm is the difficulty of its hardware implementation due to the involved computational efforts.

Hence, Fuzzy logic controller (FLC) is employed to reduce the difficulty of the IC hardware implementation. FLC is a rule-based control technique which does not rely on specific model of the controlled object and has good robustness to instabilities. It is particularly suitable for the implementation 
of difficult systems. Fuzzy logic controllers have the advantages of working with inexact inputs and handling nonlinearity. In FLC, basic control action is determined by a set of language rules dictated by the system's operation.

\section{CONCEPT OF MPPT}

The concept of Maximum Power Point Tracking (MPPT) is very unique to the fields of photovoltaic (PV) systems. A solar cell has a current to voltage (I-V) curve that is very similar to that of the PV module or array. This is because the PV module is merely an interconnection of PV cells. I-V curve is usually defined for a unique set of temperature and irradiance conditions. For instance, if the irradiance or illuminations were to increase, the I-V curve will change to a higher level. In general, a higher irradiance gives a better I-V curve, and a higher temperature gives a worse I-V curve as depicted in fig. 1

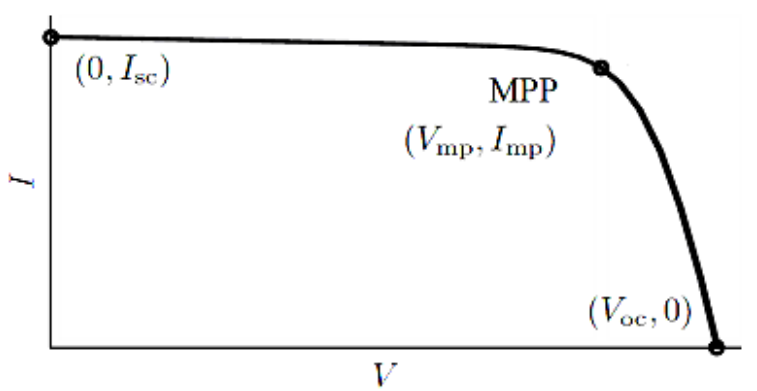

Fig.1: Current-voltage (I-V) Characteristic curve of a PV module [8]

The power-voltage (P-V) curve is also another characteristic curve of a PV module and takes the form as shown in fig.2. An operating point on the I-V curve also corresponds to a unique operating point on the P-V curve. The power at the operating point on the $\mathrm{P}-\mathrm{V}$ curve is actually the power that is produced and delivered to the rest of the PV systems and eventually the load. Therefore, it is clearly advantageous that a solar module operates at maximum power.

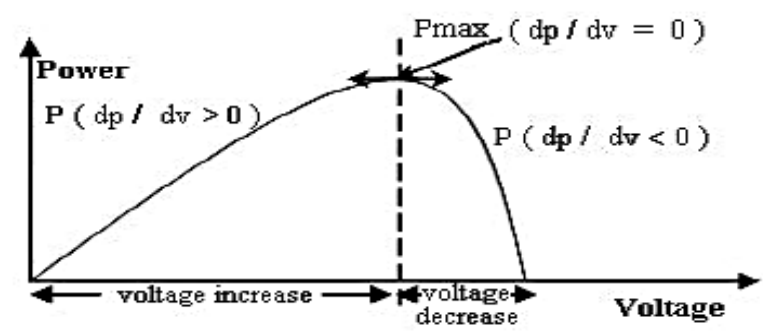

Fig.2: Power-voltage (P-V) characteristic curve of a PV module [9]

Without any form of external electrical manipulations, the PV module's operating point is largely dictated by the electrical load seen by the PV module at its output. To get maximum power delivered by the PV system, it is therefore imperative to force the PV module to operate at the operating point corresponding to the maximum power point (MPP) [10]. This point is the peak of the $\mathrm{P}-\mathrm{V}$ curve or the knee of the I-V curve. Both the I-V curve and the P-V curve changes with change in ambient conditions and thus the maximum power point as well. Thus to be continuously at maximum power point at all times, there is need to track any such changes on the I-V or P-V curve so as to locate the new MPP. This process is called MPPT. The devices that perform this process are called MPP trackers [11].

\section{MODELING OF PV CELL}

The equivalent circuit of a PV cell is shown in Fig.4.

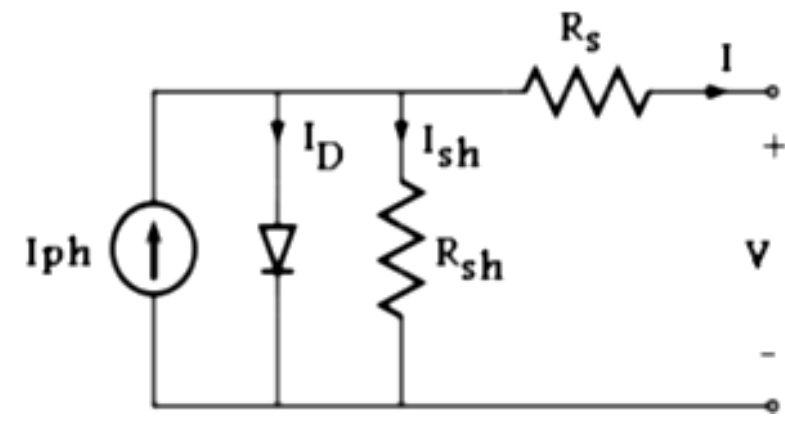

Fig.3: PV cell equivalent circuit [12]

The current source Iph represents the cell photocurrent while $R s h$ and $R s$ are the intrinsic shunt and series resistances of the cell, respectively. Usually the value of $R s h$ is very large and that of $R s$ is very small, hence they may be neglected to simplify the analysis.

The conversion of solar radiation into electricity by the photovoltaic process is one of the exploitation means of solar potential. A photovoltaic panel is mathematically modeled as follows:

The photo generated current of photovoltaic cell is expressed using Kirchhoff's current law by the following equation [13].

$I_{p h}=I_{D}+I_{s h}+I$

Where $I_{p h}$ is the photo-generated current, $I_{s h}$ is the shunt current; $I_{D}$ is the diode current,

$I$ is the output current,

From equation (1), the output current is expressed as:

$$
I=I_{p h}-I_{D}-I_{s h}
$$

The diode current is expressed as:

$$
I_{D}=I_{o}\left(e^{\frac{V}{n \mathrm{~V}_{t}}}\right)-1
$$

Where $I_{O}$ is module saturation current, $V$ is module voltage $(\mathrm{V}), n$ is an ideality factor of the diode, $V_{t}$ is diode thermal voltage $(\mathrm{V})$.

The shunt current on the other hand is expressed as

$$
I_{s h}=\left(\frac{V+\mathrm{I} R_{s}}{R_{p}}\right)
$$

Where $V$ is PV module voltage $(\mathrm{V}), R_{s}$ is series resistor $(\Omega)$, I is PV module current (A), $R_{p}$ is parallel resistor $(\Omega)$,

Substituting $I_{D}$ and $I_{s h}$ in equation (2), the output current is: 


$$
I=N_{p} I_{p h}-N_{p} I_{o}\left(e^{\frac{V}{n \mathrm{~V}_{t}}}\right)-1
$$

The thermal voltage of the diode is given by:

$V_{t}=\frac{N_{S} K T}{q}$

Where $N_{P}$ is the number of modules connected in parallel, $N_{S}$ is the number of cells connected in series, $K$ is Boltzmann constant, $T$ is operating temperature $(\mathrm{K}), q$ is electron charge.

The equation (5) becomes;

$$
I=N_{p} I_{p h}-N_{p} I_{o}\left(e^{\frac{q V}{n K T N s}}\right)-1
$$

The photo-generated current is expressed as:

$$
I_{p h}=\left(\mathrm{I}_{s c}+K i\left(T-T_{r}\right)\right) \frac{G}{G_{r}}
$$

Where $I_{s c}$ is short-circuit current (A), $T_{r}$ is Reference temperature $(\mathrm{K}), \mathrm{T}$ is operating temperature $(\mathrm{K}), \mathrm{G}$ is actual solar irradiation $\left(\mathrm{W} / \mathrm{m}^{2}\right), G_{r}$ is Reference solar irradiation $\left(\mathrm{W} / \mathrm{m}^{2}\right)$.

The module saturation current is expressed as:

$\left.I_{o}=I_{o n}\left(\left(\frac{T}{T_{r}}\right)^{\wedge} 3 * e^{\left(\frac{q E_{g}}{n K}\right.}\right) *\left(\left(\frac{1}{T_{r}}\right)-\left(\frac{1}{T}\right)\right)\right)$

where $T_{r}$ is Reference temperature, $\mathrm{T}$ is operating cell temperature in Kelvin; $E_{g}$ is Band gap energy for silicon, $I_{o n}$ is modules reverse saturation current.

The modules reverse saturation current $I_{o n}$ is given by:

$$
I_{o n}=\frac{I_{S C}}{e^{\frac{q V_{O C}}{n K T N s}}-1}
$$

Where $\mathrm{q}$ is electron charge, $I_{S C}$ is short circuit current (A), $V_{o c}$ is Open-circuit voltage $(\mathrm{V})$, Ns is number of cells connected in series, $\mathrm{n}$ is an ideality factor of the diode, $\mathbf{K}$ is Boltzmann constant; $T$ is operating cell temperature $(\mathrm{K})$.

\subsection{PV parameter specifications}

The parameter specifications of PV module are listed in table1.

Table1: Electrical characteristics data of SLP20-12U PV module

Name SLP20-12U

Rated power $\left(P_{m p}\right)$ 20W

Voltage at maximum power $\left(V_{m p}\right)$

Current at maximum power ( $\left.I_{m p}\right)$

Open circuit voltage $\left(V_{o c}\right)$

$21.6 \mathrm{~V}$
Short circuit current $\left(I_{s c}\right)$

$1.31 \mathrm{~A}$

Short Circuit Temp Coeff. $\left(K_{i}\right)$

$0.065 \mathrm{~A} / O_{C}$

Open circuit temp coefficient $\left(K_{v}\right)$

$-80 \mathrm{~A} / o_{C}$

Total number of cells in series $\left(N_{s}\right)$

36

Total number of cells in parallel $\left(N_{p}\right)$

1

\section{MPPT CONTROL TECHNIQUES 4.1 Fuzzy Controller}

Fuzzy logic control provides an automatic control algorithm by using linguistic variables which may take any value between 0 and 1 [14]. This algorithm does not require an accurate mathematical model and so the uncertainties such as non-linear operating characteristics and unexpected changes in the operating point can be dealt with easily. This makes FLC more suitable for handling non-linear problems [15].

The FLC system as shown in fig.4 has four processing stages namely: fuzzification, inference mechanism, rule base, and defuzzification [16].

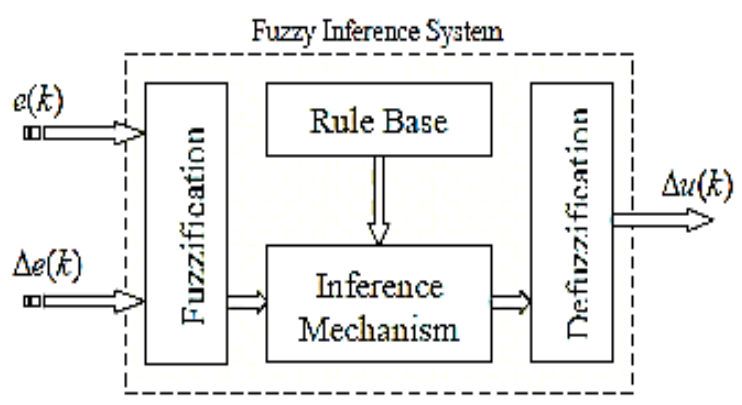

Fig.4: The basic structure of fuzzy logic based controller [17]

\subsubsection{Fuzzification}

The fuzzification interface gets the values of input variables, performs a scale mapping to transfer the range of values of input variables into corresponding universes of discourse, and performs the function of fuzzification to convert input crisp data into fuzzy values using membership functions such as trapezoidal, sigmoidal, and triangular [18].

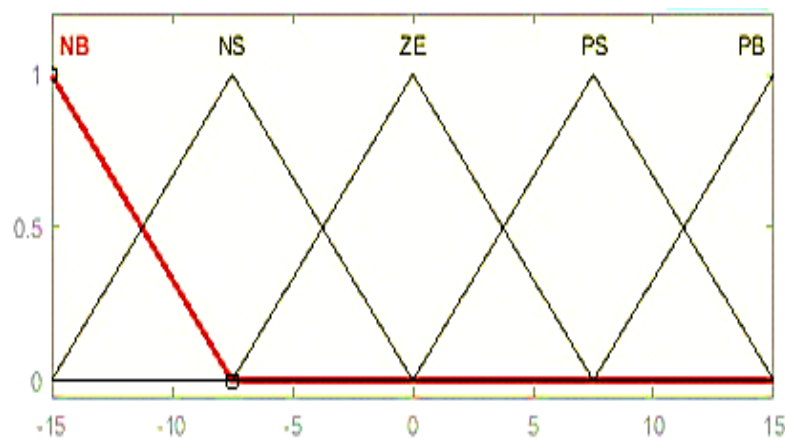

Fig.5: Input membership functions of error, e 


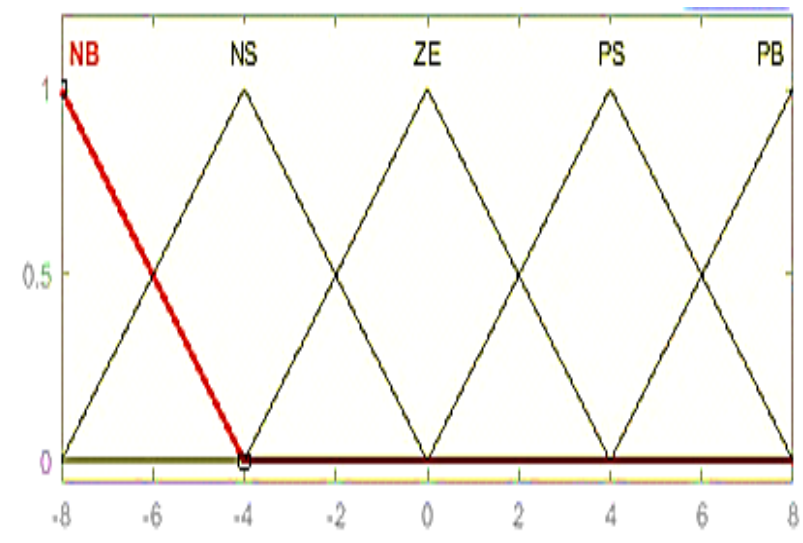

Fig.6: Input membership functions of change in error, de

\subsubsection{Rule base}

Fuzzy logic uses fuzzy rules to make a decision and generate the control action instead of using a mathematical formula [19]. This represents in a structured way the control policy in the form of a set of production rules such as:

If <process state> then <control action>

The 'if' part of the rule refer to the antecedent and the 'then' part refer to the consequent as summarized in table 2 .

\section{Table2: Fuzzy-rule-base}

\begin{tabular}{|c|c|c|c|c|c|}
\hline e & NB & NS & ZE & PS & PB \\
\hline NB & PS & PB & NB & NB & NS \\
\hline NS & PS & PS & NS & NS & NS \\
\hline
\end{tabular}

\begin{tabular}{|c|c|c|c|c|c|}
\hline ZE & ZE & ZE & ZE & ZE & ZE \\
\hline PS & NS & NS & PS & PS & PS \\
\hline PB & NS & NB & PB & PB & PS \\
\hline
\end{tabular}

\subsubsection{Inference mechanism}

The inference mechanism acts on the fuzzified inputs to fire some set of rules in the rule base [20]. The results are fuzzy sets which are reshaped using appropriate implication method and finally aggregated into a single fuzzy set. The task of the design engineer here is to specify the appropriate implication and aggregation methods to be used. Several composition methods such as Max-Min and Max-Dot have been proposed in the literature. In this study, 'Min' method is used. The output membership function of each rule is given by the minimum operator.

\subsubsection{Defuzzification}

Defuzzification is for the aggregation of the duty cycles from each rule. Given a fuzzy set that enclose a range of output values, the defuzzifier returns one number, thereby moving from a fuzzy set to a crisp number [21]. Many defuzzification procedures are highlighted in the literatures which include centre of gravity, centre of largest area, first of maxima, middle of maxima, weighted sum, weighted average, and so on.

Fig.7 and fig. 8 shows the Simulation Model of fuzzy, perturb and observe controller.

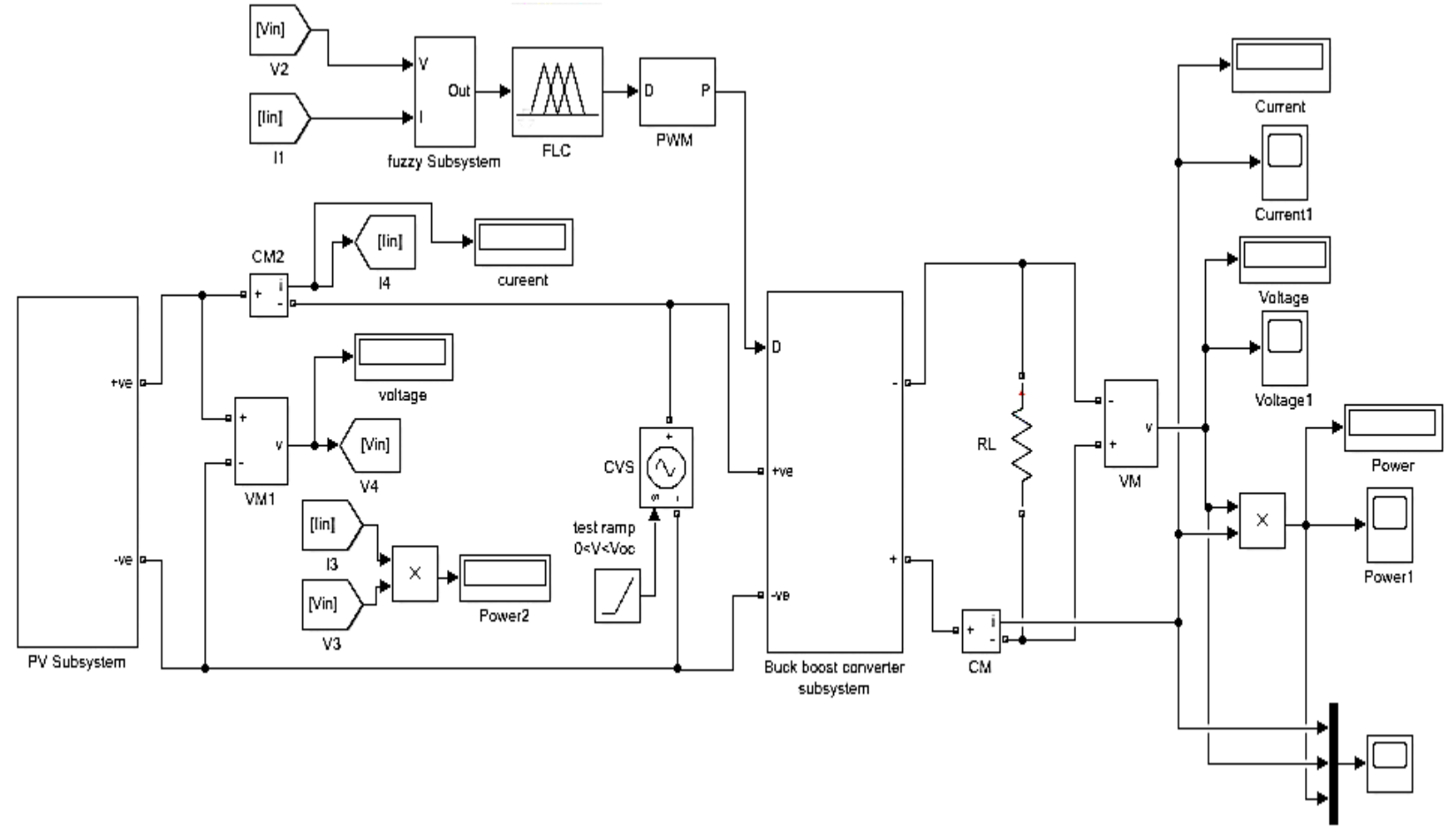

Fig.7: Matlab/Simulink model of PV system with fuzzy logic controller (FLC) based on incremental conductance technique. 


\subsection{Perturb and Observe ( $P$ and $O)$ Controller}

$\mathrm{P}$ and $\mathrm{O}$ controller block model shown in fig. 8 simulates the $\mathrm{P}$ and O MPPT algorithm. The duty cycle $\mathrm{D}(\mathrm{k})$ used to drive the converter is determined by updating the previous value $\mathrm{D}(\mathrm{k}-1)$.

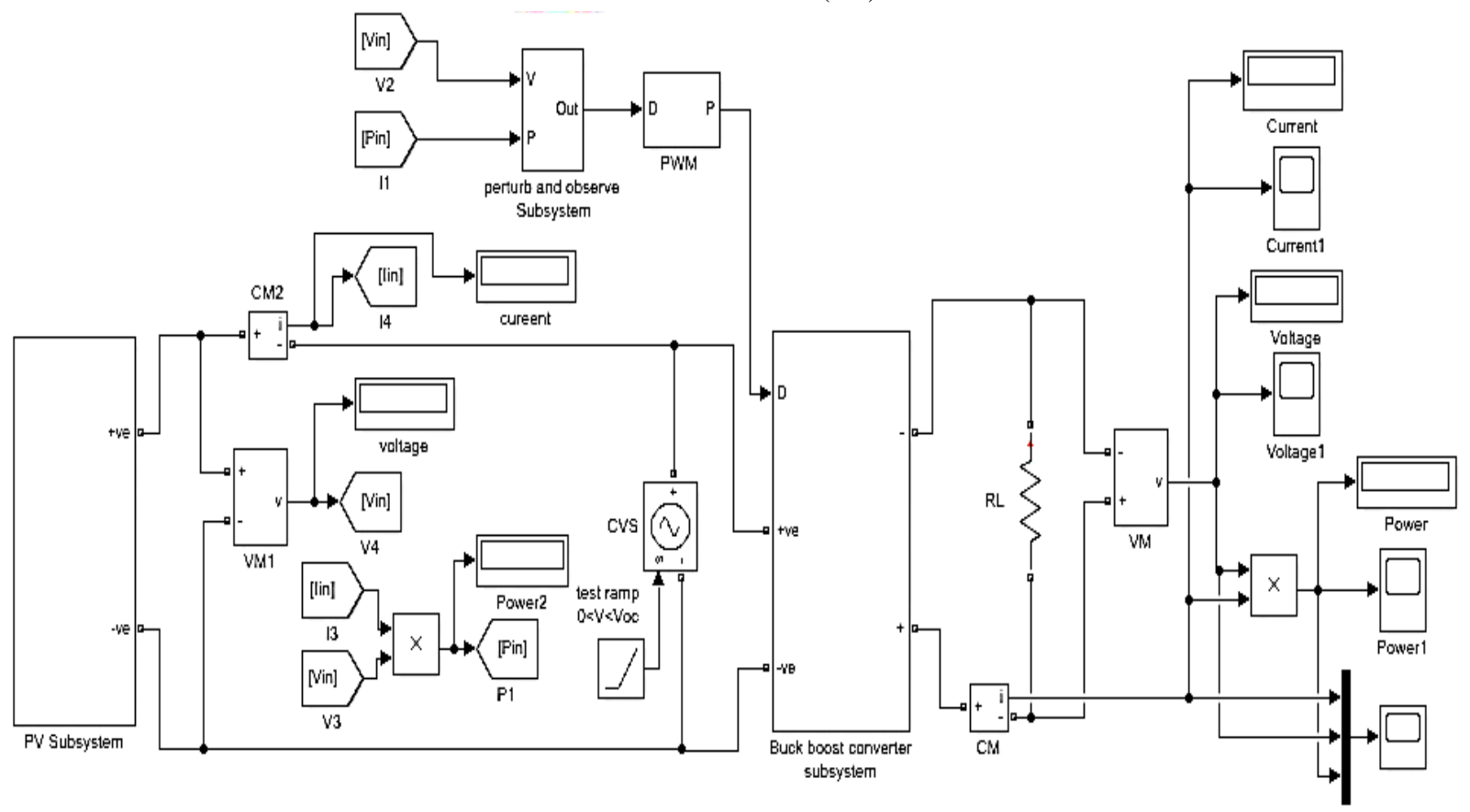

Fig.8: Matlab/Simulink model of PV system with perturb and observe (P and $O$ ) controller

\section{SIMULATION RESULTS}

The fuzzy algorithm based on incremental conductance technique was simulated using matlab/Simulink software on the model presented in fig.7. The fuzzy succeeds in changing the duty cycle of the buck-boost converter to obtain the output power of the module at its maximum value. Fig.9 and fig. 10 show the results in this case. Under $10 \Omega$ load, the output power remained at steady state with no overshoot.

The $\mathrm{P}$ and $\mathrm{O}$ algorithm was simulated using matlab/Simulink software on the model presented in fig. 8 for the same conditions applied in fuzzy logic. The $\mathrm{P}$ and $\mathrm{O}$ succeed in changing the duty cycle of the buck-boost converter to attain the output power of the module at its maximum value. Fig.11 and fig. 12 show the results in this case. Under $10 \Omega$ load, the output power remained at steady state with no overshoot, but with chattering behaviour around the MPP which may lead to loss of power.

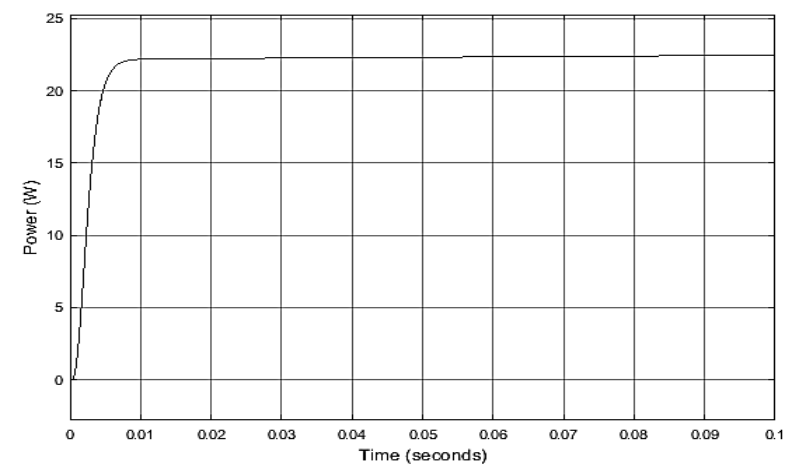

Fig.9: Fuzzy response under fixed load of $10 \Omega$ at $1000 \mathrm{~W} / \mathrm{m} 2$ irradiance

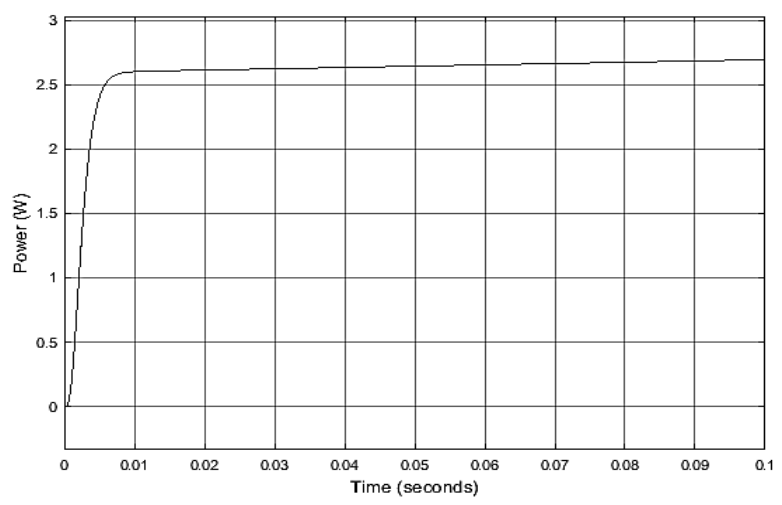

Fig.10: Fuzzy response under fixed load of $10 \Omega$ at 200W/m2 irradiance

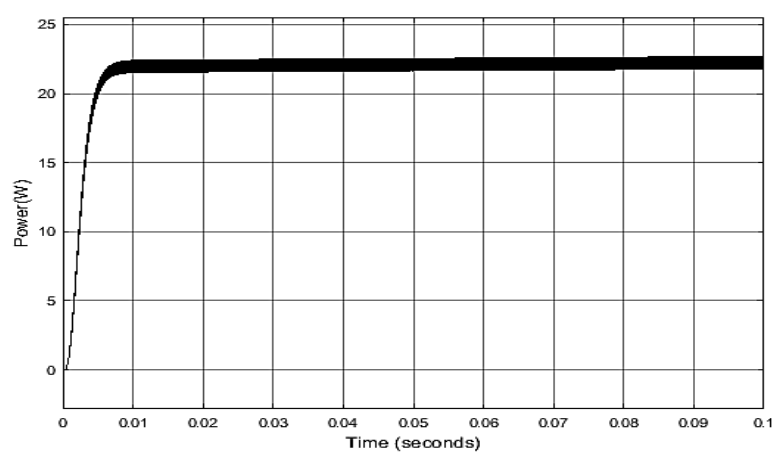

Fig.11: $P$ and $O$ response under fixed load of $10 \Omega$ load at $1000 \mathrm{~W} / \mathrm{m} 2$ irradiance 


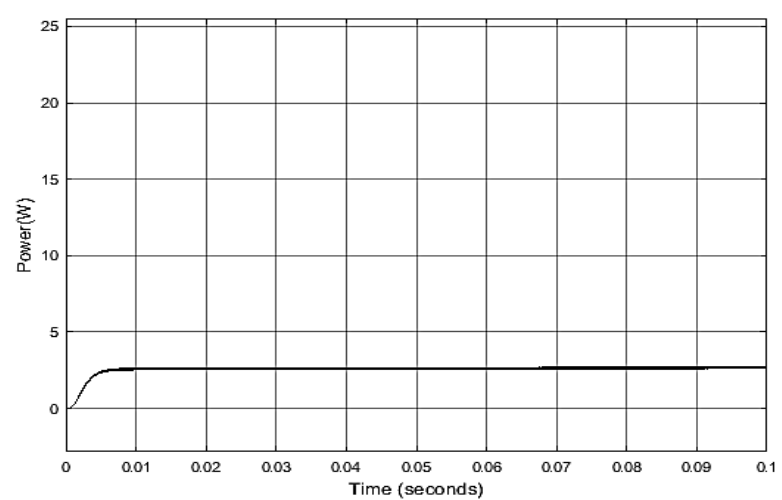

Fig.12: $P$ and $O$ response under fixed load of $10 \Omega$ at 200W/m2 irradiance

The fuzzy MPPT controller presented in fig. 9 and fig. 10 shows better stability with less oscillation around the MPP as compared with the Perturb and Observe algorithm in fig.11 and fig. 12 which has much oscillation around the MPP which may lead to loss of power.

\section{CONCLUSION}

The simulation results of the MPPT controllers obtained shows that, fuzzy incremental based controller output is more stable with less oscillation at the MPP than that of the conventional $\mathrm{P}$ and $\mathrm{O}$ controller which has much oscillation around the MPP.

\section{REFERENCES}

[1] M. A. Daud, M. Z., Mohamed, A., Ibrahim, A. A. and Hannan, "Heuristic optimization of state-of-charge feedback controller parameters for output power dispatch of hybrid photovoltaic/ battery energy storage system," Measurement, vol. 49, no. 1, pp. 15-25, 2014.

[2] V. R. Kolluru, R. K. Patjoshi, and R. Panigrahi, "A Comprehensive Review on Maximum Power Tracking of a Photovoltaic System Under Partial Shading Conditions," Int. J. Renew. Energy Res., vol. 9, no. 1, pp. 175-186, 2019.

[3] C. S. Kumari, J. S. and Babu, "Mathematical Modeling and Simulation of Photovoltaic Cell using MatlabSimulink Environment," Int. J. Electr. Comput. Eng., vol. 2, no. 1, pp. 26-34, 2012.

[4] H. Raedani, R. and Muhammad, "Design, testing and comparison of $\mathrm{P} \& \mathrm{O}$, IC and VSSIR MPPT techniques," in IEEE International Conference, 2014, pp. 322-330.

[5] S. Maissa, F. and Lassâad, Efficiency Boosting for PV Systems- MPPT Intelligent Control Based. 2015.

[6] M. Houssamo, I., Locment, F. and Sechilariu, "Experimental analysis of impact of MPPT methods on energy efficiency for photovoltaic power systems," Int. J. Electr. Power Energy Syst., vol. 46, no. 1, pp. 98-107, 2013.

[7] S. Mekhilef, K. S. and Tey, "Modified incremental conductance MPPT algorithm to mitigate inaccurate responses under fastchanging solar irradiation level," Sol. Energy, vol. 101, pp. 333-342, 2014.

[8] V. K. Jha and S. Bhandari, "Comparative Study of Fuzzy Logic MPPT Controllers, using Different Membership Functions - for PV Modules," Impending Power Demand Innov. Energy Paths, pp. 397-407, 2013.

[9] D. Bawa and C. Y. Patil, "Fuzzy control based solar tracker using Arduino Uno," Int. J. Eng. Innov. Technol., vol. 2, no. 12, pp. 179-187, 2013.

[10] M. S. Ibbini and A. H. Adawi, "Analysis and design of a maximum power point tracker for a stand-alone photo voltaic system using simscape," Int. J. Adv. Trends Comput. Sci. Eng., vol. 8, no. 1, pp. 6-10, 2019.

[11] M. Samia, L., Mabrouk, K. and Mohammed, "Design of the MPPT in PV System," IPCO, pp. 1-6, 2015.

[12] R. A. Nerissa E. L. Anku, D. Adu-Gyamfi, A. Kankam, A. Takyi, "A Model for Photovoltaic Module Optimisation,” J. Mech. Eng. Autom., vol. 5, no. 2, pp. 72-79, 2015.

[13] Z. Z. A. H. Mazinan, "Maximum power point tracking of the solar power plants in shadow mode through artificial neural network," Complex Intell. Syst., pp. 1-16, 2019.

[14] W. Muhammad, A. K., Saon, S. and Sweechee, "Development of optimum controller based on MPPT for photovoltaic system during shading condition," Procedia Eng., vol. 53, pp. 337-346, 2013.

[15] S. Manimekakai, P., Harikumar, R. and Raghavan, "A hybrid MPPT with interleaved converter for standalone PV power generation system," Int. Energy J., vol. 14, pp. 143-154, 2014.

[16] D. Sushma, N. and Srinivas, "A new fuzzy based improved incremental conductance algorithm for tracking the MPP of a solar PV panel," Int. J. Prof. Eng. Stud., vol. 9, no. 1, pp. 156-163, 2017.

[17] S. Stjepanovic, A., Softic, F., Bundalo, Z. and Stjepanovic, "Solar Tracking System and Modelling of PV Module,” MIPRO 2010, Opatija, Crotia, 2010.

[18] Z. Eltawil, M. A. and Zhao, "MPPT techniques for photovoltaic applications," Renew. Sustain. Energy Rev., pp. 793-813, 2013.

[19] C. P. Roy, D. Vijaybhaskar, and T. Maity, "Modelling of Fuzzy Logic Controller For variable- step MPPT in Photovoltaic System,” IJRET Int. J. Res. Eng. Technol., vol. 2, no. 8, pp. 426-432, 2013.

[20] A. I. Camilla, M. Muthuselvi, A. I. Camilla, and M. Muthuselvi, "Maximum Power Point Tracking For Standalone Photovoltaic System,” Int. J. Technol. Innov. Res., vol. 14, pp. 1-12, 2015.

[21] F. A. Cavalcanti, M. C., Oliveira, K. C., Azevedo, G. M., Moreira, D. and Neves, "Maximum power point tracking techniques for photovoltaic systems," Int. J. Eng. Dev. Res., vol. 4, no. 2, pp. 49-56, 2016. 